\title{
Ultrasound-Enhanced Hot Air Drying of Germinated Highland Barley Seeds: Drying Characteristics, Microstructure, and Bioactive Profile
}

\author{
Yan Song ${ }^{1}$, Yang Tao ${ }^{1}$, Xiaoyu Zhu ${ }^{1,2, *}$, Yongbin Han ${ }^{1, *}$, Pau Loke Show ${ }^{3}$, Changnain Song ${ }^{4}$ \\ and Hayyiratul Fatimah Mohd Zaid ${ }^{5}$ \\ 1 College of Food Science and Technology, Nanjing Agricultural University, Nanjing 210095, China; \\ 2016108021@njau.edu.cn (Y.S.); yang.tao@njau.edu.cn (Y.T.) \\ 2 College of Food Science, Tibet Agriculture \& Animal Husbandry University, Nyingchi 860000, China \\ 3 Department of Chemical and Environmental Engineering, Faculty of Science and Engineering, \\ University of Nottingham Malaysia, Jalan Broga, Semenyih 43500, Selangor Darul Ehsan, Malaysia; \\ PauLoke.Show@nottingham.edu.my \\ 4 College of Horticulture, Nanjing Agricultural University, Nanjing 210095, China; \\ songchangnian@njau.edu.cn \\ 5 Fundamental and Applied Sciences Department, Centre of Innovative Nanostructures \& \\ Nanodevices (COINN), Institute of Autonomous System, Universiti Teknologi PETRONAS, \\ Bandar Seri Iskandar 32610, Malaysia; hayyiratul.mzaid@utp.edu.my \\ * Correspondence: zhuxiaoyu@njau.edu.cn (X.Z.); hanyongbin@njau.edu.cn (Y.H.)
}

Received: 24 September 2019; Accepted: 8 October 2019; Published: 14 October 2019

\begin{abstract}
The effects of ultrasound-enhanced hot air drying on the drying characteristics, microstructure and bioactive profile of germinated highland barley seeds (GHB) were studied. GHB was dried by hot air at $55{ }^{\circ} \mathrm{C}$ and $70{ }^{\circ} \mathrm{C}$ and ultrasonic intensities of $125.1 \mathrm{~W} / \mathrm{dm}^{2}$ and 180.2 $\mathrm{W} / \mathrm{dm}^{2}$, respectively. The results showed that when the drying temperature was $55^{\circ} \mathrm{C}$ or $70{ }^{\circ} \mathrm{C}$, the sonicated groups could shorten the drying time by $17.4-26.1 \%$ or $18.8-31.3 \%$, respectively. Ultrasound drying at $125.1 \mathrm{~W} / \mathrm{dm}^{2}$ and $55{ }^{\circ} \mathrm{C}$ could mostly increase the content of organic selenium and the rehydration rate, improve the color and maintain the original structure of GHB. Compared with hot air drying alone, the phenolic content did not increase due to ultrasound-enhanced hot air drying. Therefore, drying at an ultrasonic intensity of $125.1 \mathrm{~W} / \mathrm{dm}^{2}$ and a temperature of $55{ }^{\circ} \mathrm{C}$ could effectively shorten the drying time, and enhance the quality of GHB.
\end{abstract}

Keywords: ultrasound-enhanced hot air drying; germinated highland barley seeds; drying characteristics; microstructure; bioactive profile

\section{Introduction}

Highland barley (Hordeum vulgare L.), as a kind of hulless barley, is a principal food crop in Tibet and the only food crop in China that grows at high altitudes of 4200-4500 m [1,2]. Additionally, highland barley is rich in nutrients, such as protein, dietary fiber and vitamins, unsaturated fatty acids, lysine and phytosterols, especially phenolic compounds [3,4]. These bioactive substances confer various physiological functions to highland barley, such as reducing hyperlipidemia and diabetes risk, and preventing chronic diseases $[4,5]$.

Selenium is an essential micronutrient for humans and mediates biological functions, such as antioxidant capacity and immune regulation [6]. Lack of selenium can cause some diseases, such as Kashin-Beck disease and Keshan disease [7]. Especially in Tibet, where soil is generally deficient in selenium, the lack of selenium has seriously affected the health of residents in the area. Therefore, it is 
particularly important to enrich selenium in an effective manner. Germination is a traditional way to improve the nutritional value of grain. Through germination, the contents of folic acid, $\gamma$-aminobutyric acid, phenolic compounds, and other bioactive substances in grain can be increased [8]. At the same time, germination is also an effective means to enrich selenium in grain. Lazo-Vélez et al. [9] found that the total selenium content of selenium-enriched germinated soybeans increased significantly after adding different concentrations of sodium selenite solution, and the total selenium content was at least 100 times higher than that of non-selenium-enriched germinated soybeans. Although selenium-enriched grains, such as brown rice and wheat, have been studied, studies on selenium-enriched highland barley have rarely been reported $[7,10]$.

Drying is a cost-effective method for the long-term preservation of grain. Hot air drying is the most common drying method. However, hot air drying takes a long time. Our previous studies revealed that hot air drying could lead to a decline in sample quality, such as browning and shrinkage, and a decrease in the rehydration rate and total phenol content [11,12]. At the same time, the microstructure of eggplant endocarp was also greatly affected during hot air drying [13]. To overcome the limitations of traditional drying processes, ultrasound-enhanced hot air drying technology is usually used to shorten the drying time and to improve product quality $[14,15]$. Ultrasonic wave, a type of mechanical wave, can vibrate medium particles and cause ultrasonic cavitation, which will increase the particle motion, change the internal structure of the material, and strengthen the water diffusion. The effects of power ultrasound on drying kinetics are based more on mechanical effects than on thermal effects. When enhancing moisture removal, this technology does not introduce a large amount of heat energy, maintaining product quality [13]. However, ultrasonic technology is mainly used to strengthen the drying process of fruit and vegetable products. The application in grain drying is still relatively rare, and no application of ultrasonic technology to the drying process of highland barley seeds has been observed.

The aims of this study were to investigate the effects of different drying temperatures $\left(55^{\circ} \mathrm{C}\right.$ and $\left.70{ }^{\circ} \mathrm{C}\right)$ and ultrasonic intensities $\left(125.1 \mathrm{~W} / \mathrm{dm}^{2}\right.$ and $\left.180.2 \mathrm{~W} / \mathrm{dm}^{2}\right)$ on the drying characteristics, microstructure, and bioactive profile in germinated highland barley seeds (GHB). This work can provide some theoretical guidance for ultrasound-enhanced hot air drying of grain.

\section{Materials and Methods}

\subsection{Materials}

Highland barley (Tibetan Qing 2000) was purchased in Nyingchi, Tibet, China. After cultivating in sodium selenite solution ( $48 \mathrm{~h}$, at a pH of 6.0 , a concentration of $10 \mathrm{mg} / \mathrm{L}$, and at $25^{\circ} \mathrm{C}$ in the dark), the highland barley seeds were rinsed, dried, and stored at $4{ }^{\circ} \mathrm{C}$ until use. The initial moisture content of GHB was determined by the AOAC method 984.25(2000), with $1.08 \pm 0.18 \mathrm{~kg} / \mathrm{kg}$ DM (dry matter).

\subsection{Drying Experiments}

GHB was dried using a combined drying equipment with hot air circulation and sonication (Figure 1). Approximately $6 \mathrm{~g}$ of GHB was placed in a tray, with a fixed wind speed of $4 \mathrm{~m} / \mathrm{s}$, drying temperatures of $55^{\circ} \mathrm{C}$ and $70{ }^{\circ} \mathrm{C}$, ultrasonic intensities of $125.1 \mathrm{~W} / \mathrm{dm}^{2}$ and $180.2 \mathrm{~W} / \mathrm{dm}^{2}$, and a drying mode of $5 \mathrm{~s}$ on $/ 5 \mathrm{~s}$ off [16], and the hot air drying treatment group was a control. During the whole drying process, GHB was quickly weighed every $10 \mathrm{~min}$, and then quickly returned to the equipment and dried until a moisture content of $0.14 \mathrm{~kg} / \mathrm{kg}$ DM was achieved. Each set of experiments was repeated three times, and the drying times were recorded. 


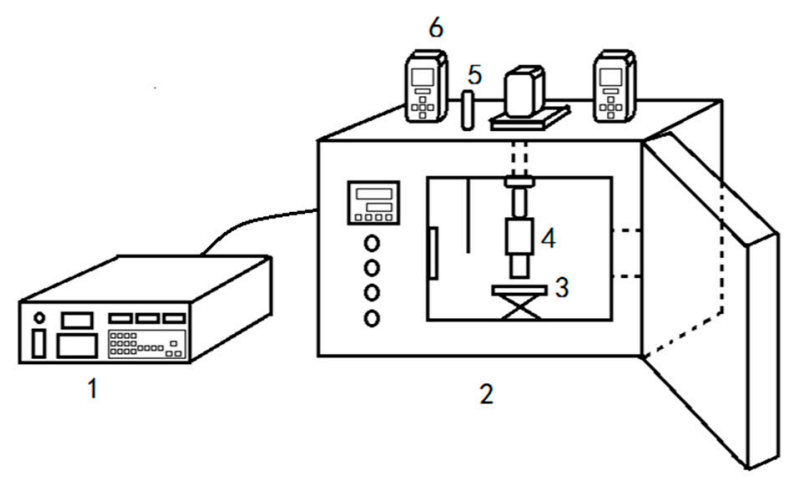

Figure 1. Schematic diagram of ultrasonic assisted hot air drying equipment. 1: ultrasonic generator; 2: drying chamber; 3: tray; 4: ultrasonic transducer; 5 : thermometer; 6 : anemometer.

\subsection{Shrinkage Pattern During Drying}

During the drying process, the length and width of GHB were quickly measured every $15 \mathrm{~min}$ and then quickly returned to the equipment until the end of drying. The shrinkage of GHB was calculated.

$$
A R=\frac{L_{l}}{L_{w}}
$$

In this equation, $A R$ represents the aspect ratio, and $L_{l}$ is the length of GHB $(\mathrm{mm})$ and $L_{w}$ is the width of GHB (mm).

\subsection{Determination of Color Properties}

The color of GHB during drying was measured using a Konica Minolta Chroma Meter (CR-400, Konica Minolta, Japan) following the method of Rawson et al. [17] with slight modifications. The instrument was calibrated using the instrument whiteboard, and the color of the sample is represented by $L^{*}, a^{*}$, and $b^{*}$ values, respectively, where $L^{*}, a^{*}$, and $b^{*}$ represent brightness, redness-greenness, and yellowness-blueness, respectively. In addition, total color difference $(\Delta E)$ was calculated using Equation (2):

$$
\Delta E=\sqrt{\left(L^{*}-L^{0}\right)^{2}+\left(a^{*}-a^{0}\right)^{2}+\left(b^{*}-b^{0}\right)^{2}}
$$

where $L^{0}, a^{0}$, and $b^{0}$ represent the $L, a$, and $b$ values of the undried GHB, respectively.

\subsection{Scanning Electron Microscopy (SEM)}

The microstructures of GHB before and after drying were investigated using a scanning electron microscope (EVO-LS10, ZEISS, Germany) following the method of Chungcharoen et al. [18] with slight modifications. GHB was cut transversely with a knife, and the samples were fixed on the preparation device with a double-sided tape, followed by gold spraying. The acceleration voltage was $10 \mathrm{kV}$ during the test, and the magnification of the sample was $\times 1000$.

The method for fixing undried samples was as follows: the samples were washed three times with a phosphate buffer saline (PBS buffer) and fixed with $2.5 \%$ glutaraldehyde at $4{ }^{\circ} \mathrm{C}$ overnight. The samples were then soaked three times with PBS buffer for 10 min each time and then successively dehydrated with $50 \%, 70 \%, 80 \%$, and $90 \%$ absolute ethanol for 15 min. Finally, the samples were dehydrated three times with absolute ethanol for 30 min each time, and the dehydrated samples were placed in a critical point desiccator for testing. 


\subsection{Rehydration}

A plurality of samples after drying in each treatment group was taken, and the initial mass was measured, after which the sample was placed in boiling water for rehydration. After rehydration for $8 \mathrm{~min}$, the GHB was taken from the boiling water to dry the surface moisture for weighing. $R$ represents the rehydration rate and was calculated by the following formula:

$$
R=\frac{m_{f}}{m_{0}}
$$

where $R$ is the rehydration rate; $m_{f}$ is the mass of the sample after rehydration; and $m_{0}$ is the mass of the sample before rehydration.

\subsection{Chemical Analysis}

Before analysis, the dried GHB obtained by different drying methods was ground into powder by an electric grinder (A11BS02, IKA, Germany).

\subsubsection{Determination of Organic Selenium Content}

The content of total selenium was assayed according to the method of Castro Grijalba et al. [19] with slight modifications. GHB powder $(0.5 \mathrm{~g})$ was digested with $10 \mathrm{~mL}$ of $\mathrm{HNO}_{3}$ and $2 \mathrm{~mL}$ of $\mathrm{H}_{2} \mathrm{O}_{2}$. After the end of digestion and cooling, the samples were transferred to a heater and heated to near dryness. Prior to determination, the Se(VI) in the samples was reduced to Se(IV) with $5 \mathrm{~mL}$ of $6 \mathrm{~mol} / \mathrm{L} \mathrm{HCl}$, and the solution was heated until white smoke appeared, after which the solution was cooled and adjusted to $10 \mathrm{~mL}$. The total selenium concentration was determined by hydride generation atomic fluorescence spectrometry (HG-AFS) after sample digestion. The conditions for HG-AFS determinations were as follows: $0.8 \%(\mathrm{w} / \mathrm{v}) \mathrm{NaBH}_{4}$ (in $0.5 \%(\mathrm{w} / \mathrm{v}) \mathrm{NaOH}$ ) and $5 \%(\mathrm{v} / \mathrm{v}) \mathrm{HCl}$. The carrier gas flow rate was $400 \mathrm{~mL} / \mathrm{min}$, the shielding gas flow rate was $900 \mathrm{~mL} / \mathrm{min}$, and the negative high voltage was $340 \mathrm{~V}$.

The inorganic selenium content in the sample was then determined. Briefly, $1 \mathrm{~g}$ of GHB powder was added to $20 \mathrm{~mL}$ of $6 \mathrm{~mol} / \mathrm{L}$ hydrochloric acid solution and was then placed in a constant temperature water bath at $70{ }^{\circ} \mathrm{C}$ and shaken for $2 \mathrm{~h}$. After cooling to room temperature, the solution was made up to $10 \mathrm{~mL}$ with a $6 \mathrm{~mol} / \mathrm{L}$ hydrochloric acid solution and filtered. Then $5 \mathrm{~mL}$ of the filtrate was taken in a tube and placed in a boiling water bath for $20 \mathrm{~min}$. After cooling to room temperature, $1 \mathrm{~mL}$ of potassium ferricyanide solution and 3 drops of n-octanol were added, water was supplemented to a volume of $25 \mathrm{~mL}$, and the sample was mixed for testing. The inorganic selenium concentration was also determined by HG-AFS, and the measurement conditions were the same as those for total selenium.

The organic selenium content was represented by the difference between the total selenium content and the inorganic selenium content.

\subsubsection{Extraction of Free and Bound Phenolic Compounds}

Free and bound phenolic compounds were extracted according to Chen et al. [8] and Wang et al. [20] with slight modifications. A total of $2 \mathrm{~g}$ of GHB powder was weighed in a centrifuge tube and extracted three times with $20 \mathrm{~mL}$ of $80 \%$ methanol under nitrogen and dark conditions for $1 \mathrm{~h}$ each time. The mixture was then centrifuged, and the supernatant was combined and subjected to rotary evaporation at $45^{\circ} \mathrm{C}$ to obtain the free phenolic acid extract. Then, $40 \mathrm{~mL}$ of $2 \mathrm{~mol} / \mathrm{L} \mathrm{NaOH}$ was added to the methanol-extracted precipitate, and the mixture was hydrolyzed for $4 \mathrm{~h}$ under nitrogen and dark conditions. The $\mathrm{pH}$ of the hydrolyzed mixture was adjusted to $1.5-2.0$ with $6 \mathrm{~mol} / \mathrm{L} \mathrm{HCl}$, and the fat in the mixture was removed with n-hexane. The mixture was extracted three times with $50 \mathrm{~mL}$ of ethyl acetate for $15 \mathrm{~min}$ each time and was then centrifuged to separate the ethyl acetate from the aqueous solution. The bound phenolic acid extract was obtained by rotary evaporation at $40^{\circ} \mathrm{C}$. 
The free and bound phenolic acid was redissolved in $10 \mathrm{~mL}$ of $50 \%$ methanol and stored at $-18{ }^{\circ} \mathrm{C}$ until use.

\subsubsection{Determination of Total Phenolic Content}

The total phenolic content was determined according to the method of Tao et al. [21]. The standard curve is drawn with the concentration of gallic acid as the abscissa and the absorbance as the ordinate. The total phenolic content is expressed as mg GAE/100 $\mathrm{g}$ DW.

\subsubsection{Determination of Phenolic Acids by High Performance Liquid Chromatography (HPLC)}

Determination of phenolic acid content was done according to the method of Chen et al. [8] with some modifications. The free and bound phenolic acid extracts prepared according to the methods described in Section 2.7.2 were taken through $0.45 \mu \mathrm{m}$ organic filters and injected, and the injection volume was $20 \mu \mathrm{L}$. The column type was Inertsil ODS-3 $5 \mu \mathrm{m}(4.6 \times 250 \mathrm{~mm}, 5 \mu \mathrm{m})$, the column temperature was $25^{\circ} \mathrm{C}$, and the measurement wavelength was $280 \mathrm{~nm}$. The mobile phase A solution was a $1 \%$ aqueous acetic acid solution, and the B solution was a $1 \%$ acetic acid methanol solution, with a flow rate of $0.6 \mathrm{~mL} / \mathrm{min}$. The gradient elution methods were as follows: $0-10 \mathrm{~min}, 10-26 \% \mathrm{~B}$; 10-25 min, 26-40\% B; 25-45 min, 40-65\% B; 45-55 min, 65-95\% B; 55-58 min, 95-100\% B; 58-65 min, $100 \% \mathrm{~B}$.

\subsection{Statistical Analysis}

All of the treatments and analyses were repeated three times, and the results are expressed as means \pm standard deviations. One-way analysis of variance (ANOVA) was performed using SPSS 20.0 (SPSS, Inc., USA) to compare the means of data about physicochemical properties of highland barley under different treatments. A $p$-value $<0.05$ was considered statistically significant, and the Duncan test was used to separate the mean differences.

\section{Results and Discussion}

\subsection{Drying Kinetics}

\subsubsection{Drying Kinetic Curves}

The drying kinetic curves of GHB at different drying temperatures are shown in Figure 2. When the drying temperatures were $55^{\circ} \mathrm{C}$ and $70{ }^{\circ} \mathrm{C}$, with the increase of ultrasonic intensity, the drying time decreased. At $55^{\circ} \mathrm{C}$, the drying times of the 125.1 and $180.2 \mathrm{~W} / \mathrm{dm}^{2}$ sonicated groups decreased by $17.4 \%$ and $26.1 \%$, respectively, compared with the unsonicated group. At $70{ }^{\circ} \mathrm{C}$, the drying times of the 125.1 and $180.2 \mathrm{~W} / \mathrm{dm}^{2}$ sonicated groups decreased by $18.8 \%$ and $31.3 \%$, respectively, compared with the unsonicated group. Ultrasound can cause rapid contraction and expansion of plant cells, resulting in the formation of bubbles in the ultrasonic sample and its surroundings. Subsequently, strong, instantaneous pressure changes, lead to changes in plant cell viscosity and surface tension, and form microscopic channels, thus effectively shortening drying time [22]. The results of this study were similar to the drying kinetics of ultrasound-enhanced hot air drying fruits and vegetables [11,14].

The drying temperature also affected the drying kinetics of GHB. As shown in Figure 2, when the ultrasonic intensities were 125.1 and $180.2 \mathrm{~W} / \mathrm{dm}^{2}$, the higher the temperature, the shorter the drying time. When the drying temperatures were $55^{\circ} \mathrm{C}$ and $70{ }^{\circ} \mathrm{C}$, the drying times required for the unsonicated group of GHB were $230 \mathrm{~min}$ and $160 \mathrm{~min}$, respectively. The drying time was shortened by $30.4 \%$ with the increase of drying temperature. When the ultrasonic intensities were 125.1 and $180.2 \mathrm{~W} / \mathrm{dm}^{2}$, the drying times were shortened by $31.6 \%$ and $35.3 \%$, respectively, with the enhancement of drying temperature. The increase in temperature could decrease the relative humidity of the air, increase the humidity gradient between the sample and the air, and speed up the moisture mobility inside the sample, thus shortening the drying time [23]. 


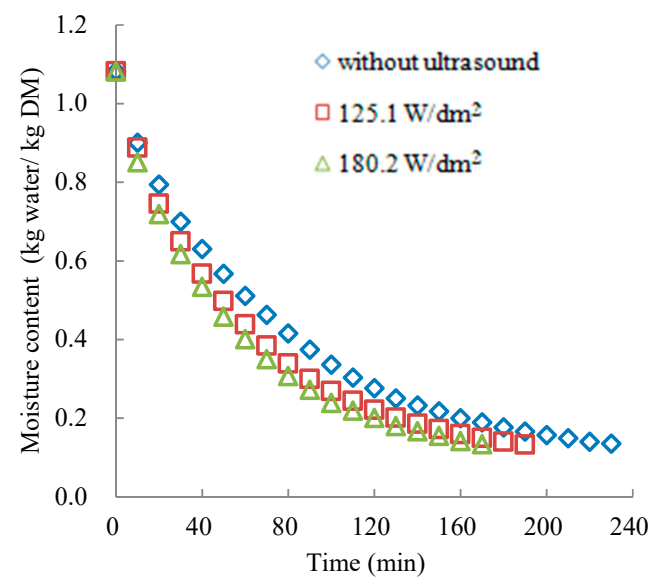

(a)

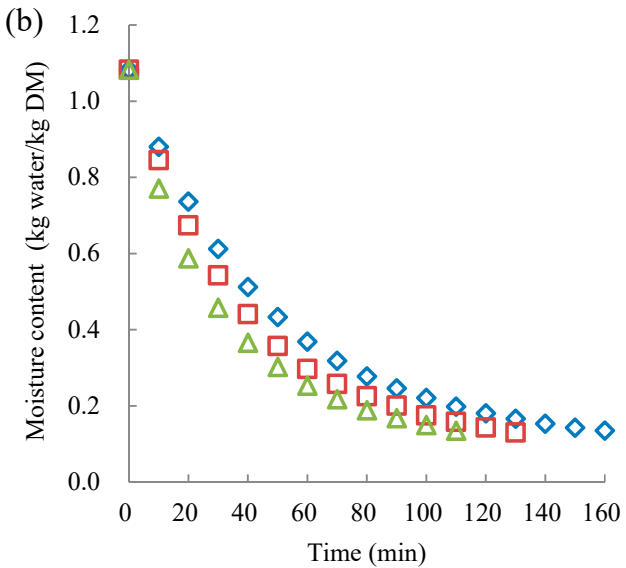

(b)

Figure 2. Drying curves of germinated highland barley seeds(GHB) under different temperatures: (a) $55^{\circ} \mathrm{C}$; (b) $70{ }^{\circ} \mathrm{C}$. DM: dry matter.

\subsubsection{Drying Rate Curves}

Under different drying temperatures and ultrasound intensities, the drying rate decreased with the drying process, and no constant rate period was observed. As seen from Figure 3, when the drying temperatures were $55^{\circ} \mathrm{C}$ and $70{ }^{\circ} \mathrm{C}$, the higher the ultrasonic intensity, the faster the drying rate. With the increase of ultrasonic intensity, the drying rate increased. At $55^{\circ} \mathrm{C}$, the initial drying rates of the treatment groups with ultrasonic intensities of 125.1 and $180.2 \mathrm{~W} / \mathrm{dm}^{2}$ increased by $6.42 \%$ and $27.52 \%$, respectively, compared with the unsonicated group. At $70{ }^{\circ} \mathrm{C}$, the initial drying rates of the treatment groups with ultrasonic intensities of 125.1 and $180.2 \mathrm{~W} / \mathrm{dm}^{2}$ increased by $17.36 \%$ and $54.55 \%$, respectively, compared with the unsonicated group. The mechanical effects of ultrasound can cause a decrease in mass transfer resistance inside and outside GHB. On the one hand, while propagating through the sample, an ultrasonic wave causes alternating expansion and contraction, and this mechanical stress helps the moisture move towards the surface of the product. On the other hand, when an ultrasonic wave is applied in a solid/gas system, the changes in oscillation speed, microfluidic, and pressure at the interface cause mechanical agitation of the gaseous medium, which facilitates the movement of moisture from the surface of the sample into the air, thereby increasing the drying rate [24].

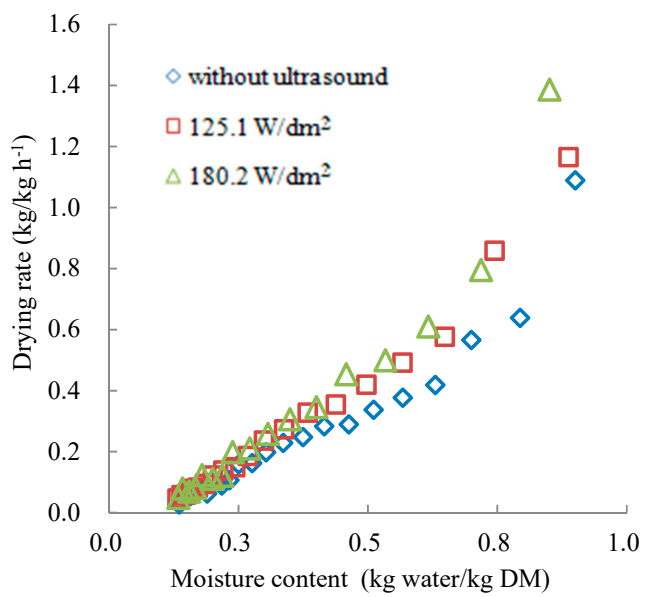

(a)

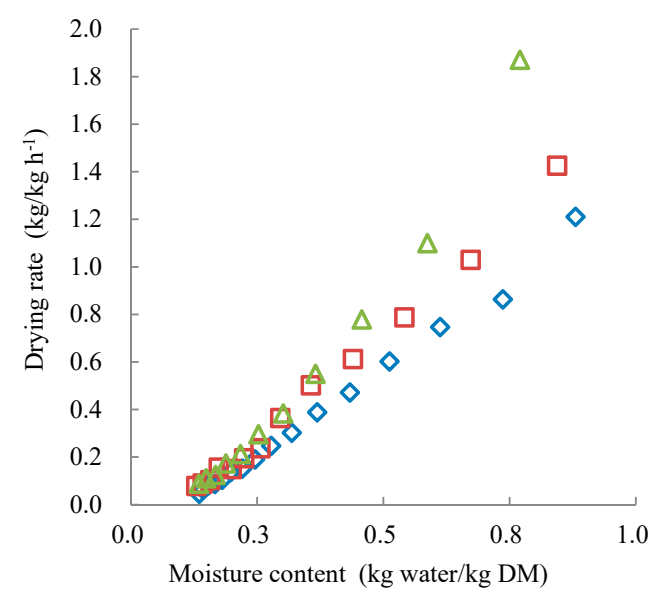

(b)

Figure 3. Drying rate curves of GHB under different temperatures: (a) $55^{\circ} \mathrm{C}$; (b) $70^{\circ} \mathrm{C}$. 
As seen from Figure 3, when the ultrasonic intensities were 125.1 and $180.2 \mathrm{~W} / \mathrm{dm}^{2}$, with the increase of drying temperature, the drying rate also increased. When the ultrasonic intensities were 125.1 and $180.2 \mathrm{~W} / \mathrm{dm}^{2}$, the initial drying rates at $70{ }^{\circ} \mathrm{C}$ were 1.22 and 1.35 times higher than those at $55^{\circ} \mathrm{C}$, respectively. A study by Lekcharoenkul et al. [25] also showed that the drying rate of cabbage leaves at $60^{\circ} \mathrm{C}$ was significantly higher than that at $45^{\circ} \mathrm{C}$.

\subsection{Shrinkage}

During the drying process, a decrease in moisture content caused the sample to shrink [11,14], which in turn caused changes in both length and width. To explore the effects of ultrasound-enhanced hot air drying on the lateral and longitudinal shrinkage of GHB, the shrinkage was studied.

According to Figure 4, the shrinkage increased during the drying process under different drying temperatures and ultrasonic intensities, indicating that the lateral shrinkage phenomenon was more pronounced than the longitudinal shrinkage during the drying process of GHB. The rate of change of shrinkage gradually decreased with the increase of drying time, indicating that the effect of the ultrasonic wave on the shrinkage of GHB was gradually weakened.

When the drying temperatures were $55^{\circ} \mathrm{C}$ and $70^{\circ} \mathrm{C}$, with the increase of ultrasonic intensity, the shrinkage increased. At $55^{\circ} \mathrm{C}$, the shrinkage levels under the 125.1 and $180.2 \mathrm{~W} / \mathrm{dm}^{2}$ sonicated groups were 1.01 and 1.02 times higher than those of the unsonicated group, respectively. At $70{ }^{\circ} \mathrm{C}$, the shrinkage levels under the 125.1 and $180.2 \mathrm{~W} / \mathrm{dm}^{2}$ sonicated groups were 1.00 and 1.01 times higher than those of the unsonicated group, respectively. These findings indicate that the larger ultrasonic intensity caused the lateral shrinkage of GHB to be more pronounced, resulting in an increase in the shrinkage.

When the intensities of the ultrasound were 125.1 and $180.2 \mathrm{~W} / \mathrm{dm}^{2}$, with the increase of drying temperature, the shrinkage also increased. When the ultrasonic intensities were 125.1 and $180.2 \mathrm{~W} / \mathrm{dm}^{2}$, the shrinkage levels at $70{ }^{\circ} \mathrm{C}$ were 1.04 and 1.04 times higher than those at $55{ }^{\circ} \mathrm{C}$, respectively, indicating that increasing the drying temperature would also cause the lateral shrinkage of GHB to be more obvious.

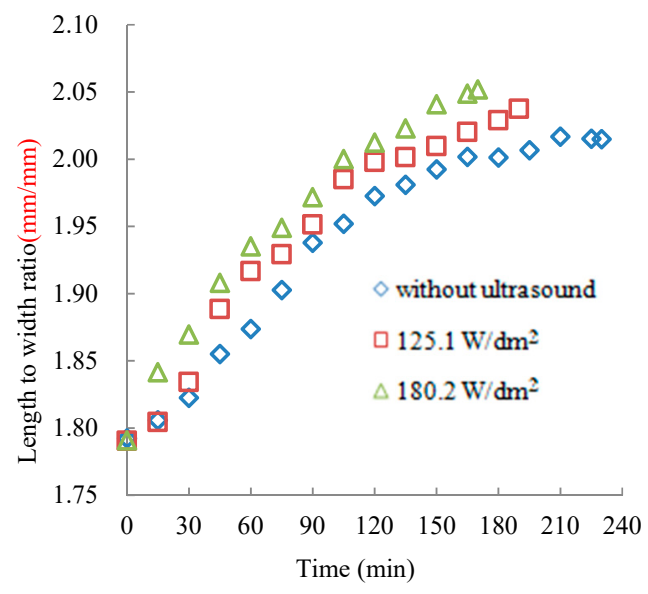

(a)

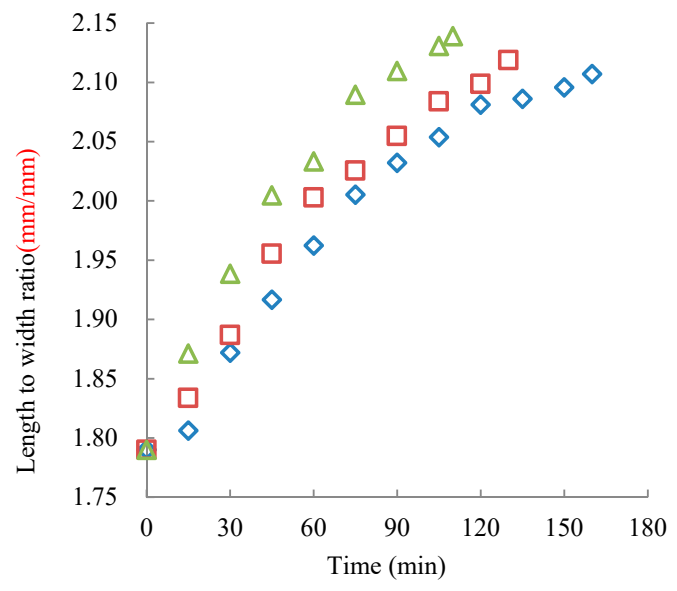

(b)

Figure 4. Shrinkage of GHB under different temperatures: (a) $55^{\circ} \mathrm{C}$; (b) $70{ }^{\circ} \mathrm{C}$.

\subsection{Color Properties}

The color properties of GHB are listed in Table 1. After drying, the $L^{*}$ values of the samples decreased significantly $(p<0.05)$, which indicated that the brightness of GHB decreased after drying. However, both the $a^{*}$ and $b^{*}$ values of the samples after drying increased significantly $(p<0.05)$. A decrease in $L^{*}$ values and an increase in $a^{*}$ values indicated an increase in browning of the samples, which is related to the Maillard reaction, caramelization reaction, and pigment degradation [26]. 
The $L^{*}$ values of GHB after ultrasonic-enhanced hot air drying were significantly higher $(p<0.05)$ than those of the unsonicated samples, indicating that GHB after ultrasonic treatment was whiter in color. Similar results were obtained during the drying of garlic slices; Tao et al. [11] reported that the $L^{*}$ values of the $216.8 \mathrm{~W} / \mathrm{m}^{3}$ and $902.7 \mathrm{~W} / \mathrm{m}^{3}$ ultrasonic-enhanced hot air dried garlic slices were significantly higher than the single hot air dried slices, and the garlic slices were whiter in color.

Table 1. Color properties of GHB under different drying methods.

\begin{tabular}{ccccc}
\hline Treatment & $\boldsymbol{L}^{*}$ & $\boldsymbol{a}^{*}$ & $\boldsymbol{b}^{*}$ & $\Delta \boldsymbol{E}$ \\
\hline Fresh & $86.75 \pm 0.29^{\mathrm{a}}$ & $2.36 \pm 0.02^{\mathrm{e}}$ & $9.89 \pm 0.04^{\mathrm{f}}$ & \\
$55-0$ & $61.65 \pm 0.41^{\mathrm{d}}$ & $8.08 \pm 0.03^{\mathrm{c}}$ & $21.68 \pm 0.13^{\mathrm{d}}$ & 28.31 \\
$55-125.1$ & $64.22 \pm 0.58^{\mathrm{b}}$ & $7.44 \pm 0.12^{\mathrm{d}}$ & $20.52 \pm 0.24^{\mathrm{e}}$ & 25.42 \\
$55-180.2$ & $63.31 \pm 0.08^{\mathrm{c}}$ & $7.97 \pm 0.09^{\mathrm{c}}$ & $21.96 \pm 0.15^{\mathrm{d}}$ & 26.95 \\
$70-0$ & $59.74 \pm 0.48^{\mathrm{e}}$ & $9.05 \pm 0.11^{\mathrm{a}}$ & $23.45 \pm 0.27^{\mathrm{a}}$ & 30.95 \\
$70-125.1$ & $63.26 \pm 0.22^{\mathrm{c}}$ & $8.55 \pm 0.05^{\mathrm{b}}$ & $23.09 \pm 0.18^{\mathrm{b}}$ & 27.64 \\
$70-180.2$ & $62.13 \pm 0.59^{\mathrm{d}}$ & $8.42 \pm 0.16^{\mathrm{b}}$ & $22.44 \pm 0.10^{\mathrm{c}}$ & 28.29
\end{tabular}

Note: $55-0$ is drying at $55^{\circ} \mathrm{C}$ without sonication; $55-125.1$ is drying at $55^{\circ} \mathrm{C}$ and $125.1 \mathrm{~W} / \mathrm{dm}^{2} ; 55-180.2$ is drying at $55^{\circ} \mathrm{C}$ and $180.2 \mathrm{~W} / \mathrm{dm}^{2} ; 70-0$ is drying at $70{ }^{\circ} \mathrm{C}$ without sonication; $70-125.1$ is drying at $70^{\circ} \mathrm{C}$ and $125.1 \mathrm{~W} / \mathrm{dm}^{2}$; $70-180.2$ is drying at $70^{\circ} \mathrm{C}$ and $180.2 \mathrm{~W} / \mathrm{dm}^{2}$. Different letters indicate significant differences in different drying methods $(p<0.05)$.

The total color difference $\Delta E$ of the dried sample and the sample before drying was calculated using $L^{*}, a^{*}$, and $b^{*}$ values. It can be seen that the $\Delta E$ values of GHB after drying by six different methods were higher than three, indicating that the color differences produced by the drying process were visible [27].

When the drying temperatures were $55^{\circ} \mathrm{C}$ and $70{ }^{\circ} \mathrm{C}$, the $\Delta E$ values of the sonicated groups were smaller than those of the unsonicated group, and the samples obtained by the $125.1 \mathrm{~W} / \mathrm{dm}^{2}$ ultrasonic treatment group have the lowest $\Delta E$ values compared with the sample before drying. These findings indicated that the $125.1 \mathrm{~W} / \mathrm{dm}^{2}$ ultrasonic-enhanced hot air drying was more effective to reduce the browning of GHB.

When the ultrasonic intensities were 125.1 and $180.2 \mathrm{~W} / \mathrm{dm}^{2}$, the $\Delta E$ value increased as the drying temperature increased, which indicated that increasing the drying temperature exacerbated the browning of the samples after drying. Therefore, drying at an ultrasonic intensity of $125.1 \mathrm{~W} / \mathrm{dm}^{2}$ and a temperature of $55^{\circ} \mathrm{C}$ was more beneficial to reduce the browning degree of GHB.

\subsection{Scanning Electron Microscopy (SEM)}

Scanning electron microscopy (SEM) was used to observe the effects of different drying methods on the microstructure of GHB. Before drying, GHB had a higher moisture content, rich tissue, and loose structure (Figure 5a). The decrease in moisture content during the drying process led to the shrinkage of the structure of GHB, which affected the release of water.

It can be clearly observed from Figure $5 \mathrm{~b}$ that the structure of GHB was destroyed, and the high degree of structural damage may be related to prolonged exposure to high-temperature air [13]. As seen from Figure $5 \mathrm{c}$,d compared with the unsonicated group, the structure of GHB in the sonicated group was well maintained. Nascimento et al. [23] found that ultrasound-enhanced hot air drying could better maintain the original structure of cells compared with traditional hot air drying of passion fruit peel. Moreover, cell shrinkage could be clearly observed by ultrasound-enhanced hot air drying. When the ultrasonic intensity was $125.1 \mathrm{~W} / \mathrm{dm}^{2}$, GHB tissue could best maintain the original structure. This might be because a moderate ultrasonic intensity $\left(125.1 \mathrm{~W} / \mathrm{dm}^{2}\right)$ of ultrasound-enhanced hot air drying could reduce the drying time and produce mild mechanical effects, which was more conducive to the retention of the GHB structure. 


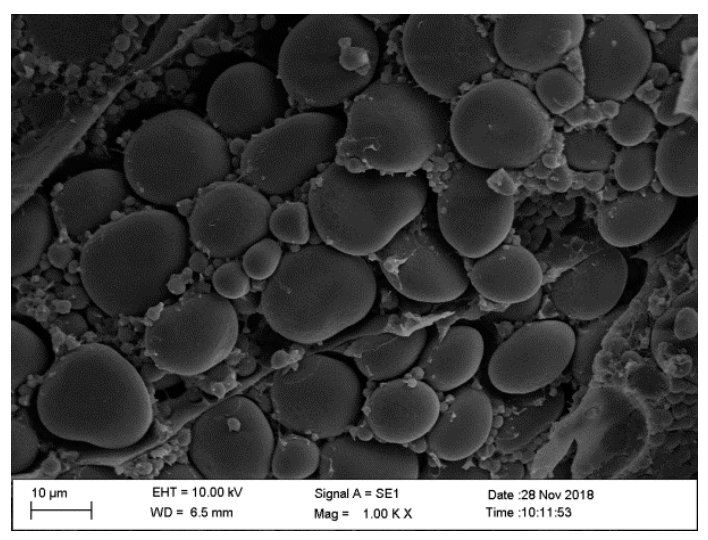

(a)

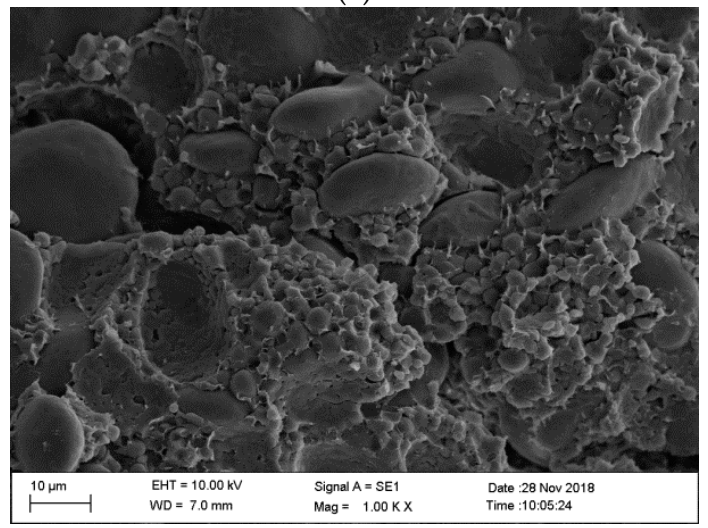

(c)

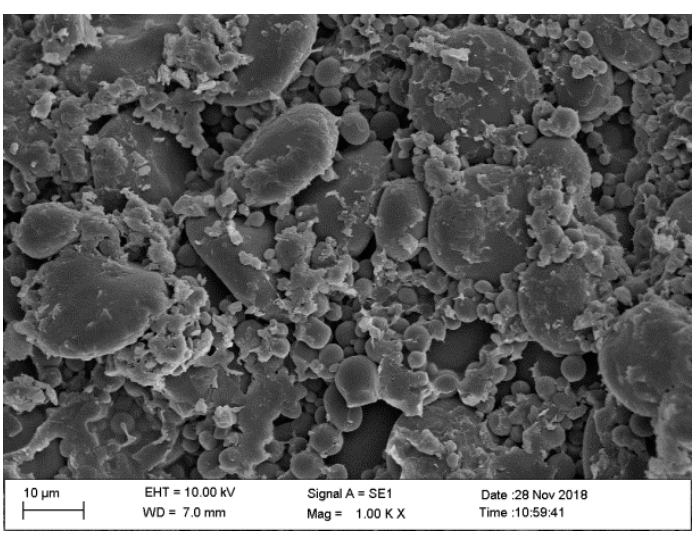

(b)

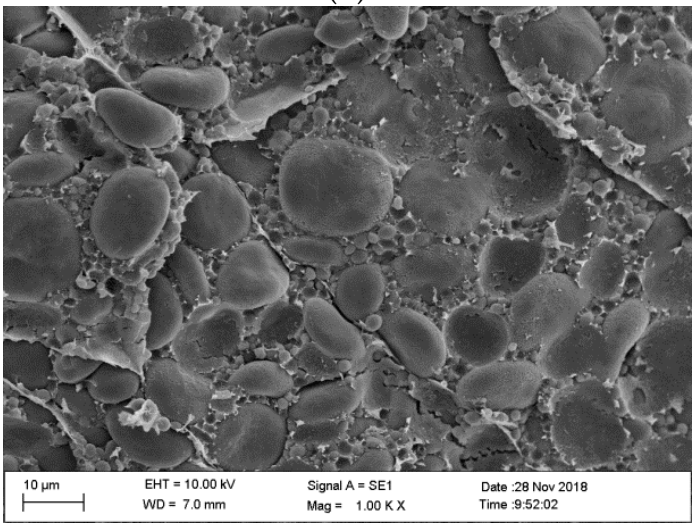

(d)

Figure 5. Scanning electron micrographs (SEM) of GHB microstructure under different drying methods: (a) before drying; (b) dried at $55{ }^{\circ} \mathrm{C}$; (c) dried at $55^{\circ} \mathrm{C}$ and $125.1 \mathrm{~W} / \mathrm{dm}^{2}$; and (d) dried at $55{ }^{\circ} \mathrm{C}$ and $180.2 \mathrm{~W} / \mathrm{dm}^{2}$.

\subsection{Rehydration}

Figure 6 shows the effects of different drying methods on the rehydration of GHB. When the drying temperatures were $55^{\circ} \mathrm{C}$ and $70{ }^{\circ} \mathrm{C}$, the rehydration rates of $\mathrm{GHB}$ in the $125.1 \mathrm{~W} / \mathrm{dm}^{2}$ sonicated group were the highest, which were 1.01 and 1.02 times higher than those of the unsonicated group, respectively. Ultrasound can cause rapid contraction and expansion of plant cells, causing bubbles to form on the ultrasonic sample and its surroundings, resulting in strong, transient pressure changes that could alter plant cell viscosity and surface tension, destroying cell walls [22]. Therefore, due to the increase in cell wall permeability, water easily entered the cell through the cell wall, resulting in an increase in the rehydration rate of GHB after $125.1 \mathrm{~W} / \mathrm{dm}^{2}$ ultrasonic-enhanced hot air drying. Accordingly, ultrasonic-enhanced hot air drying could improve the rehydration characteristics of cabbage and dried green pepper [12,28]. It can be seen from Figure 5 that the ultrasonic intensity of $180.2 \mathrm{~W} / \mathrm{dm}^{2}$ caused the structure of GHB to be too tight, which was not conducive to the transportation of water, reducing the rehydration rate. When the ultrasonic intensities were 125.1 and $180.2 \mathrm{~W} / \mathrm{dm}^{2}$, the drying temperature had no significant effect on the rehydration rate of GHB $(p>0.05)$. 


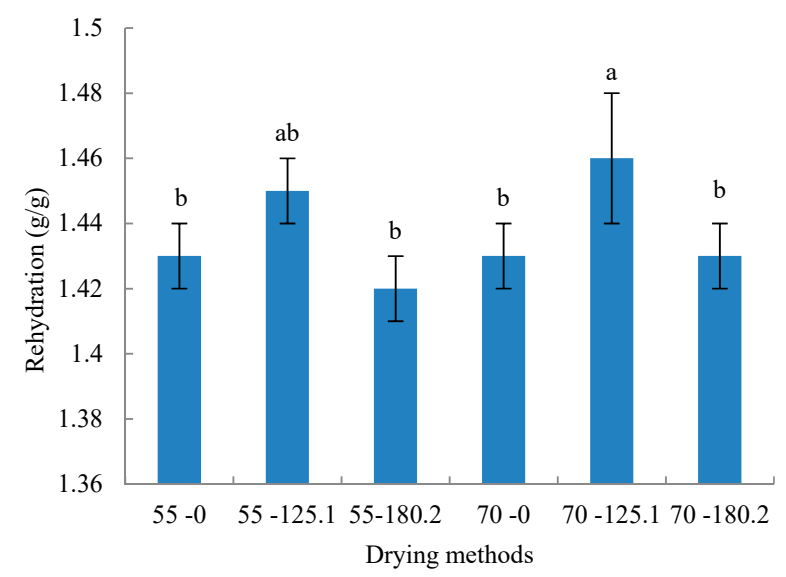

Figure 6. Effects of different drying methods on rehydration of GHB. Note: $55-0$ is drying at $55^{\circ} \mathrm{C}$ without sonication; $55-125.1$ is drying at $55^{\circ} \mathrm{C}$ and $125.1 \mathrm{~W} / \mathrm{dm}^{2} ; 55-180.2$ is drying at $55^{\circ} \mathrm{C}$ and $180.2 \mathrm{~W} / \mathrm{dm}^{2} ; 70-0$ is drying at $70^{\circ} \mathrm{C}$ without sonication; $70-125.1$ is drying at $70{ }^{\circ} \mathrm{C}$ and $125.1 \mathrm{~W} / \mathrm{dm}^{2}$; $70-180.2$ is drying at $70^{\circ} \mathrm{C}$ and $180.2 \mathrm{~W} / \mathrm{dm}^{2}$. Different letters indicate significant differences in different drying methods $(p<0.05)$.

\subsection{Effects of Different Drying Methods on the Contents of Organic Selenium in GHB}

As shown in Figure 7a, the contents of organic selenium in GHB after drying by different drying methods were significantly higher than that in the sample before drying $(p<0.05)$. Selenite was absorbed by plants to form selenide under the catalysis of glutathione. Selenide formed selenium-containing amino acids such as SeCys, SeMet, and others under the catalysis of amino acid synthase.

Selenium-containing amino acids are among the most important forms of organic selenium in plants. In the process of drying, free selenide may be converted into selenium-containing amino acids by the action of amino acid synthase, which elevates the content of organic selenium in GHB.

Ultrasonic waves destroy the original tissue structure of plants, thereby promoting the extraction of phytochemicals [22]; however, excessive ultrasonic intensity may destroy the produced organic selenium, resulting in a decrease in its content. When the drying temperatures were $55^{\circ} \mathrm{C}$ and $70{ }^{\circ} \mathrm{C}$, the contents of organic selenium in GHB of the $125.1 \mathrm{~W} / \mathrm{dm}^{2}$ sonicated group were 1.10 and 1.06 times higher than those of the unsonicated group, respectively. When the ultrasonic intensity increased to $180.2 \mathrm{~W} / \mathrm{dm}^{2}$, the content of organic selenium in GHB after drying was significantly lower than in the the $125.1 \mathrm{~W} / \mathrm{dm}^{2}$ sonication group $(p<0.05)$.

The drying temperature also affected the organic selenium content in GHB. When the drying temperature was $55{ }^{\circ} \mathrm{C}$, the contents of organic selenium in $\mathrm{GHB}$ of the unsonicated group and the 125.1 and $180.2 \mathrm{~W} / \mathrm{dm}^{2}$ sonicated groups were $1.06,1.10$, and 1.45 times higher than those drying at $70{ }^{\circ} \mathrm{C}$, respectively. Higher drying temperatures may result in a decrease in the activity of the amino acid synthase, which in turn reduces the amount of organic selenium synthesized during the drying process; therefore, a lower drying temperature was more conducive to increasing the retention rate of the organic selenium. 


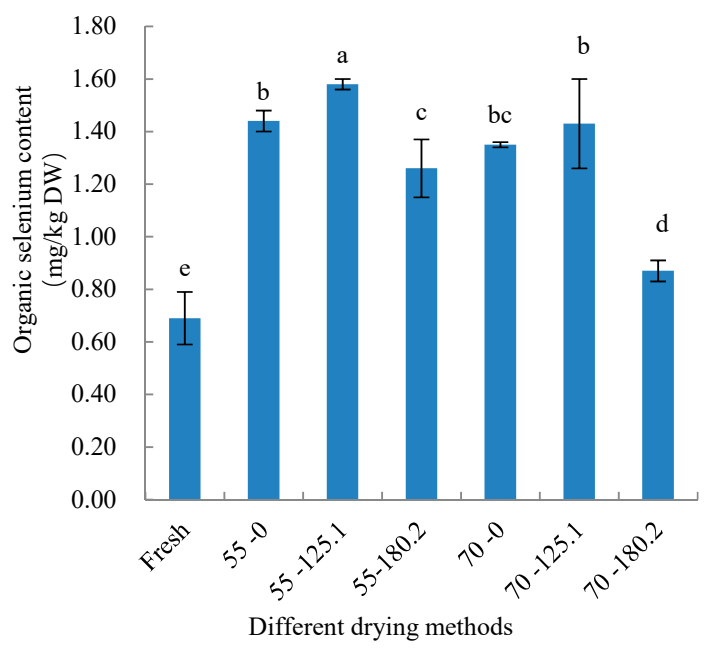

(a)

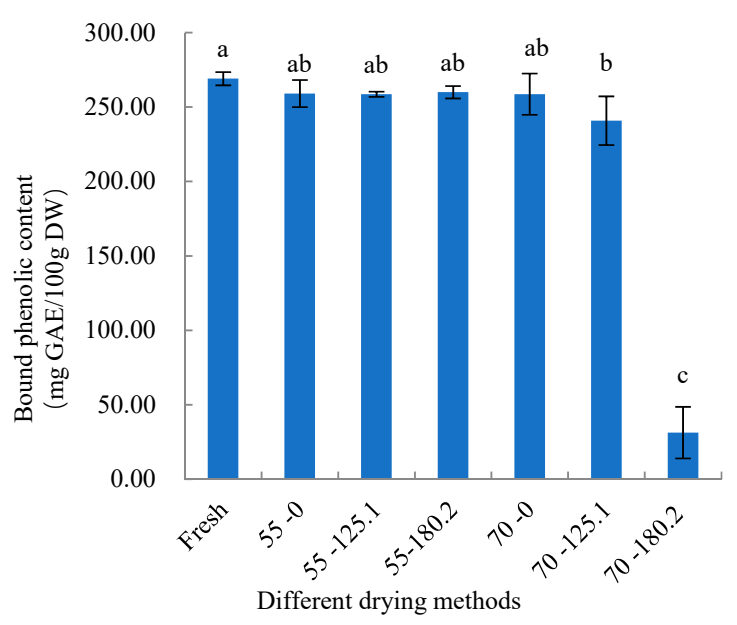

(c)

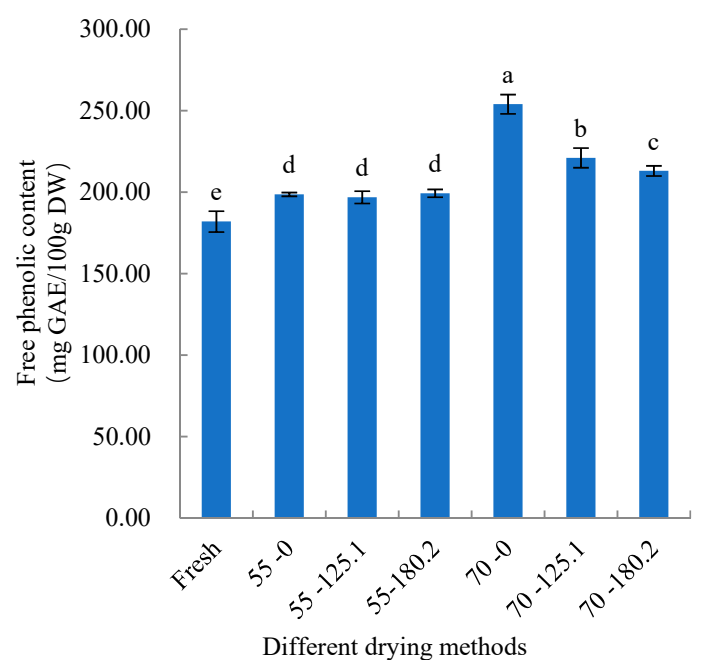

(b)

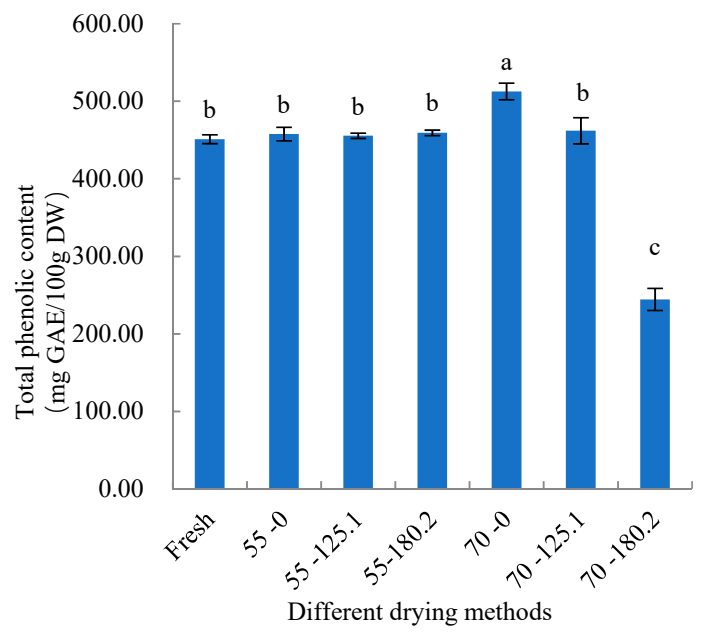

(d)

Figure 7. Effects of different drying methods on the contents of (a) organic selenium, (b) free phenolic, (c) bound phenolic, and (d) total phenolic in GHB. Note: $1.55-0$ is drying at $55^{\circ} \mathrm{C}$ without sonication; $55-125.1$ is drying at $55^{\circ} \mathrm{C}$ and $125.1 \mathrm{~W} / \mathrm{dm}^{2} ; 55-180.2$ is drying at $55^{\circ} \mathrm{C}$ and $180.2 \mathrm{~W} / \mathrm{dm}^{2} ; 70-0$ is drying at $70{ }^{\circ} \mathrm{C}$ without sonication; $70-125.1$ is drying at $70{ }^{\circ} \mathrm{C}$ and $125.1 \mathrm{~W} / \mathrm{dm}^{2} ; 70-180.2$ is drying at $70{ }^{\circ} \mathrm{C}$ and $180.2 \mathrm{~W} / \mathrm{dm}^{2}$. Different letters indicate significant differences in different drying methods $(p<0.05)$.

\subsection{Effects of Different Drying Methods on the Contents of Free, Bound, and Total Phenolic in GHB}

The effects of different drying methods on the free phenolic content are plotted in Figure $7 \mathrm{~b}$. The contents of free phenolic in GHB after drying by six different drying methods were significantly higher than that before drying $(p<0.05)$ and drying at $70{ }^{\circ} \mathrm{C}$ had the highest free phenolic content. At $55^{\circ} \mathrm{C}$, the effects of different ultrasonic intensities on free phenolic content were not significantly different $(p>0.05)$. At $70{ }^{\circ} \mathrm{C}$, the free phenolic content decreased significantly with the increase of ultrasonic intensities $(p<0.05)$.

At $70^{\circ} \mathrm{C}$, the contents of free phenolic in GHB of the unsonicated group and the 125.1 and 180.2 W/dm ${ }^{2}$ sonicated groups were $1.28,1.12$, and 1.07 times higher than those drying at $55^{\circ} \mathrm{C}$, respectively. This may be because drying at $55{ }^{\circ} \mathrm{C}$ required longer drying time, which led to more significant degradation of free phenolic by hot air [29].

It can be seen from Figure 7c that different drying methods led to a decrease in bound phenolic content in GHB and drying at an ultrasonic intensity of $180.2 \mathrm{~W} / \mathrm{dm}^{2}$ and a temperature of $70{ }^{\circ} \mathrm{C}$ 
resulted in a significant decrease in bound phenolic content $(p<0.05)$. After drying with this method, the bound phenolic content was only $11.62 \%$ of the sample before drying. There was no significant difference in bound phenolic content obtained by other drying methods $(p>0.05)$. Folin-Ciocalteu reagent reacts not only with polyphenols but also with other reducing compounds, such as vitamin $C$, amino acids, and Maillard reaction products. Therefore, the reduction of bound phenolic content during drying may be related to the decreases in vitamin $C$ and amino acid content [30]. Furthermore, a bound phenolic substance with a larger molecular weight during the drying process may be decomposed into a simple free phenolic substance by the heat treatment, resulting in a decrease in the bound phenolic content and an increase in the free phenolic content.

The effects of different drying methods on the total phenolic content of GHB are shown in Figure $7 \mathrm{~d}$. As seen, when the drying temperature was $55^{\circ} \mathrm{C}$, there were no significant differences among the effects of different ultrasonic intensities on total phenolic content $(p>0.05)$. At $70^{\circ} \mathrm{C}$, the total phenolic content decreased with the increase of ultrasonic intensity, and the total phenolic content of GHB obtained from the unsonicated group was the highest. Non-enzymatic reactions such as Maillard and caramelization reactions caused by high temperature during drying may lead to an increase in total phenolic content [31]. After drying at an ultrasonic intensity of $125.1 \mathrm{~W} / \mathrm{dm}^{2}$ and a temperature of $70^{\circ} \mathrm{C}$, the total phenolic content of GHB was not significantly different from that before drying $(p>0.05)$, while drying at an ultrasonic intensity of $180.2 \mathrm{~W} / \mathrm{dm}^{2}$ and a temperature of $70^{\circ} \mathrm{C}$ resulted in a significant decrease in total phenolic content in GHB $(p<0.05)$. Higher drying temperatures and ultrasonic intensities can cause cellular damage, which in turn may lead to the loss of phenolic substances [32].

\subsection{Effects of Different Drying Methods on the Contents of Free and Bound Phenolic Acids in GHB}

The contents of free phenolic acids before and after drying are listed in Table 2. Five kinds of phenolic acids, such as protocatechuic acid, chlorogenic acid, phloretin, catechin, and ferulic acid, were detected in the free phenolic acids extract of GHB, and the protocatechuic acid content was the highest. After drying at an ultrasonic intensity of $180.2 \mathrm{~W} / \mathrm{dm}^{2}$ and a temperature of $70{ }^{\circ} \mathrm{C}$, the protocatechuic acid content was significantly reduced $(p<0.05)$; however, there were no significant differences among other drying methods $(p>0.05)$. Drying at an ultrasonic intensity of $180.2 \mathrm{~W} / \mathrm{dm}^{2}$ and a temperature of $55{ }^{\circ} \mathrm{C}$ resulted in the loss of chlorogenic acid until it could not be detected, as well as drying at a temperature of $70^{\circ} \mathrm{C}$. Other drying conditions also resulted in a decrease in chlorogenic acid content. The drying temperature of $70^{\circ} \mathrm{C}$ led to the loss of phloretin until it was not detected. The phloretin content at the drying temperature of $55^{\circ} \mathrm{C}$ first increased and then decreased with the increase in ultrasonic intensities. There was no significant difference in the effects of different drying methods on catechin and ferulic acid contents $(p>0.05)$. When the drying temperature was $55^{\circ} \mathrm{C}, 125.1 \mathrm{~W} / \mathrm{dm}^{2}$ ultrasonic-enhanced hot air drying was more conducive to improve the retention of free phenolic acids. When the drying temperature was $70^{\circ} \mathrm{C}$, the separate hot air drying was more conducive to increase the retention of free phenolic acids.

Table 2. Effect of different drying methods on free phenolic acids contents in GHB.

\begin{tabular}{cccccc}
\hline $\begin{array}{c}\text { Free Phenolic Acids Contents } \\
\text { (mg/100g DW) }\end{array}$ & Protocatechuic Acid & Chlorogenic Acid & Phloretin & Catechin & Ferulic Acid \\
\hline Fresh & $13.80 \pm 0.92^{\mathrm{a}}$ & $4.55 \pm 0.10^{\mathrm{a}}$ & $1.27 \pm 0.02^{\mathrm{a}}$ & $2.28 \pm 0.08^{\mathrm{a}}$ & $1.21 \pm 0.03^{\mathrm{bc}}$ \\
$55-0$ & $11.80 \pm 0.18^{\mathrm{cd}}$ & $4.35 \pm 0.02^{\mathrm{b}}$ & $1.28 \pm 0.03^{\mathrm{a}}$ & $1.77 \pm 0.18^{\mathrm{b}}$ & $1.25 \pm 0.02^{\mathrm{ab}}$ \\
$55-125.1$ & $12.55 \pm 0.45^{\mathrm{bc}}$ & $4.40 \pm 0.01^{\mathrm{b}}$ & $1.30 \pm 0.03^{\mathrm{a}}$ & $2.17 \pm 0.33^{\mathrm{ab}}$ & $1.28 \pm 0.01^{\mathrm{a}}$ \\
$55-180.2$ & $10.77 \pm 1.51^{\mathrm{d}}$ & nd & $1.18 \pm 0.04^{\mathrm{b}}$ & $2.06 \pm 0.14^{\mathrm{ab}}$ & $1.22 \pm 0.04^{\mathrm{bc}}$ \\
$70-0$ & $14.04 \pm 0.33^{\mathrm{a}}$ & nd & nd & $2.47 \pm 0.00^{\mathrm{a}}$ & $1.19 \pm 0.02^{\mathrm{c}}$ \\
$70-125.1$ & $13.58 \pm 0.38^{\mathrm{ab}}$ & nd & nd & $2.21 \pm 0.08^{\mathrm{ab}}$ & $1.19 \pm 0.04^{\mathrm{c}}$ \\
$70-180.2$ & $9.44 \pm 0.23^{\mathrm{e}}$ & nd & nd & $2.43 \pm 0.56^{\mathrm{a}}$ & $1.19 \pm 0.04^{\mathrm{c}}$ \\
\hline
\end{tabular}

Note: $55-0$ is drying at $55^{\circ} \mathrm{C}$ without sonication; $55-125.1$ is drying at $55^{\circ} \mathrm{C}$ and $125.1 \mathrm{~W} / \mathrm{dm}^{2} ; 55-180.2$ is drying at $55^{\circ} \mathrm{C}$ and $180.2 \mathrm{~W} / \mathrm{dm}^{2} ; 70-0$ is drying at $70^{\circ} \mathrm{C}$ without sonication; $70-125.1$ is drying at $70^{\circ} \mathrm{C}$ and $125.1 \mathrm{~W} / \mathrm{dm}^{2}$; $70-180.2$ is drying at $70^{\circ} \mathrm{C}$ and $180.2 \mathrm{~W} / \mathrm{dm}^{2}$. The "nd" denotes that the content could not be detected. Different letters indicate significant differences in each column $(p<0.05)$. 
The contents of bound phenolic acids before and after drying are listed in Table 3. Seven phenolic acids were detected in the bound phenolic acid extract of GHB: ferulic acid, catechin, p-coumaric acid, quercetin, cinnamic acid, phloretin, and caffeic acid. Ferulic acid was the main phenolic compound in GHB and mainly existed in the bound fraction [5]. This study also showed that the content of ferulic acid in the bound phenolic acid of GHB was the highest after drying, but different drying methods would lead to a decrease in its content. When the drying temperature was $55^{\circ} \mathrm{C}$, the bound phenolic acids contents of the sonication and unsonicated groups were not very different. When the drying temperature was $70^{\circ} \mathrm{C}$, the ultrasonic intensity of $180.2 \mathrm{~W} / \mathrm{dm}^{2}$ caused a significant decrease in the bound phenolic acids content $(p<0.05)$, and no catechin, quercetin, cinnamic acid, and phloretin was detected after the end of drying. It may be that the combination of high temperature and high intensity of the ultrasonic wave destroyed the bound phenolic acids structure in GHB and caused its content to decrease. At the same ultrasonic intensities, the bound phenolic acid content at a drying temperature of $55^{\circ} \mathrm{C}$ was higher than that at a drying temperature of $70^{\circ} \mathrm{C}$, which indicated that a higher drying temperature was more likely to cause loss of bound phenolic acids.

Table 3. Effect of different drying methods on bound phenolic acids contents in GHB.

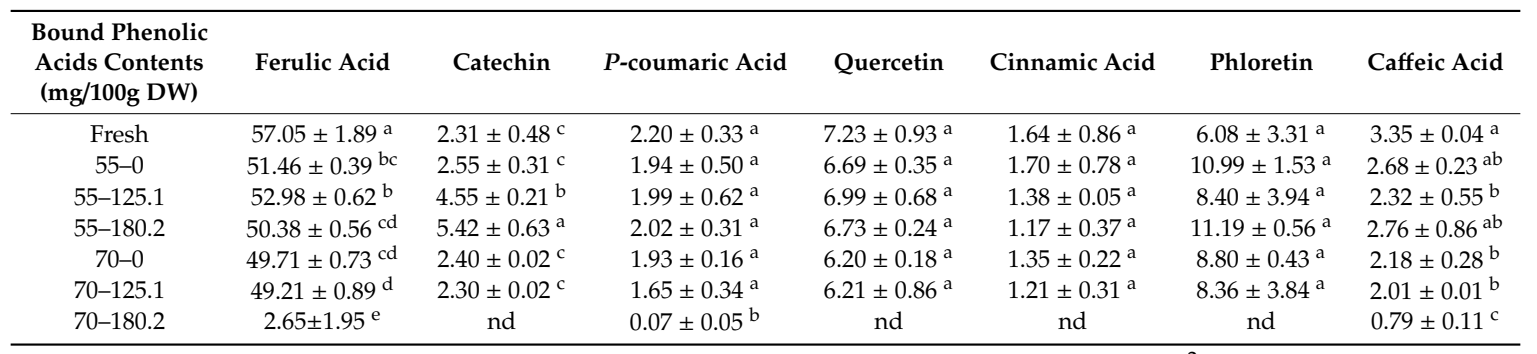

Note: $55-0$ is drying at $55^{\circ} \mathrm{C}$ without sonication; $55-125.1$ is drying at $55^{\circ} \mathrm{C}$ and $125.1 \mathrm{~W} / \mathrm{dm}^{2} ; 55-180.2$ is drying at $55^{\circ} \mathrm{C}$ and $180.2 \mathrm{~W} / \mathrm{dm}^{2} ; 70-0$ is drying at $70{ }^{\circ} \mathrm{C}$ without sonication; $70-125.1$ is drying at $70{ }^{\circ} \mathrm{C}$ and $125.1 \mathrm{~W} / \mathrm{dm}^{2}$; $70-180.2$ is drying at $70^{\circ} \mathrm{C}$ and $180.2 \mathrm{~W} / \mathrm{dm}^{2}$. The "nd" denotes that the content could not be detected. Different letters indicate significant differences in each column $(p<0.05)$.

\section{Conclusions}

Compared with hot air drying, ultrasound-enhanced hot air drying could effectively improve the drying rate and shorten the drying time. The increase in the ultrasonic intensity and drying temperature worked to strengthen the effects. However, the strengthening effects of ultrasound was weakened by the decrease in water content of GHB during drying. Compared with the longitudinal shrinkage, the lateral shrinkage of GHB during drying was more obvious. The higher the ultrasonic intensity was, the more obvious the lateral shrinkage of GHB. Drying at an ultrasonic intensity of $125.1 \mathrm{~W} / \mathrm{dm}^{2}$ and a temperature of $55{ }^{\circ} \mathrm{C}$ could reduce the browning degree of GHB, improve its rehydration rate, and better maintain its original structure.

It was not observed that ultrasound-enhanced hot air drying could increase the content of phenolic substances. The main beneficial effect of ultrasound-enhanced hot air drying on the quality of GHB was the preservation of organic selenium. Therefore, ultrasonic technology could be used to strengthen the drying process of GHB which had a higher bioactive content and was better in quality after being dried by hot air at $55{ }^{\circ} \mathrm{C}$ with an ultrasonic intensity of $125.1 \mathrm{~W} / \mathrm{dm}^{2}$.

Author Contributions: Conceptualization, Y.T.; Data curation, Y.S.; Funding acquisition, X.Z. and H.F.M.Z.; Investigation, Y.S. and Y.T.; Methodology, Y.S.; Project administration, X.Z.; Resources, X.Z.; Supervision, Y.H.; Writing-Original Draft, Y.S.; Writing-Review \& Editing, Y.T., P.L.S. and C.S.

Funding: This research was funded by Natural Science Foundation of Tibet Autonomous region (No. XZ2017ZRG -31), Provincial Natural Science Fund of Jiangsu, China (No. BK20140708), Yayasan Universiti Teknologi PETRONAS (No. YUTP 015LC0-047).

Conflicts of Interest: The authors declare no conflict of interest. 


\section{References}

1. Cheng, D.; Zhang, X.; Meng, M.; Han, L.; Li, C.; Hou, L.; Qi, W.; Wang, C. Inhibitory effect on HT-29 colon cancer cells of a water-soluble polysaccharide obtained from highland barley. Int. J. Biol. Macromol. 2016, 92, 88-95. [CrossRef] [PubMed]

2. Liu, Z.; Yao, Z.; YU, C.; Zhong, Z. Assessing crop water demand and deficit for the growth of spring highland barley in Tibet, China. J. Integr. Agric. 2013, 12, 541-551. [CrossRef]

3. Liu, K.; Zhang, B.; Chen, L.; Li, X.; Zheng, B. Hierarchical structure and physicochemical properties of highland barley starch following heat moisture treatment. Food Chem. 2019, 271, 102-108. [CrossRef] [PubMed]

4. Lin, S.; Guo, H.; Gong, J.D.B.; Lu, M.; Lu, M.; Wang, L.; Zhang, Q.; Qin, W.; Wu, D. Phenolic profiles, $\beta$-glucan contents, and antioxidant capacities of colored Qingke (Tibetan hulless barley) cultivars. J. Cereal Sci. 2018, 81, 69-75. [CrossRef]

5. Zhu, Y.; Li, T.; Fu, X.; Abbasi, A.M.; Zheng, B.; Liu, R.H. Phenolics content, antioxidant and antiproliferative activities of dehulled highland barley (Hordeum vulgare L.). J. Funct. Foods 2015, 19, 439-450. [CrossRef]

6. Zhou, F.; Yang, W.; Wang, M.; Miao, Y.; Cui, Z.; Li, Z.; Liang, D. Effects of selenium application on Se content and speciation in Lentinula edodes. Food Chem. 2018, 265, 182-188. [CrossRef] [PubMed]

7. Liu, K.; Zhao, Y.; Chen, F.; Fang, Y. Purification and identification of Se-containing antioxidative peptides from enzymatic hydrolysates of Se-enriched brown rice protein. Food Chem. 2015, 187, 424-430. [CrossRef]

8. Chen, Z.; Wang, P.; Weng, Y.; Ma, Y.; Gu, Z.; Yang, R. Comparison of phenolic profiles, antioxidant capacity and relevant enzyme activity of different Chinese wheat varieties during germination. Food Biosci. 2017, 20 , 159-167. [CrossRef]

9. Lazo-Vélez, M.A.; Guardado-Félix, D.; Aviles-González, J.; Romo-López, I.; Serna-Saldívar, S.O. Effect of germination with sodium selenite on the isoflavones and cellular antioxidant activity of soybean (Glycine max). LWT Food Sci. Technol. 2018, 93, 64-70. [CrossRef]

10. Lazo-Vélez, M.A.; Avilés-González, J.; Serna-Saldivar, S.O.; Temblador-Pérez, M.C. Optimization of wheat sprouting for production of selenium enriched kernels using response surface methodology and desirability function. LWT Food Sci. Technol. 2016, 65, 1080-1086. [CrossRef]

11. Tao, Y.; Zhang, J.; Jiang, S.; Xu, Y.; Show, P.-L.; Han, Y.; Ye, X.; Ye, M. Contacting ultrasound enhanced hot-air convective drying of garlic slices: Mass transfer modeling and quality evaluation. J. Food Eng. 2018, 235, 79-88. [CrossRef]

12. Tao, Y.; Han, M.; Gao, X.; Han, Y.; Show, P.-L.; Liu, C.; Ye, X.; Xie, G. Applications of water blanching, surface contacting ultrasound-assisted air drying, and their combination for dehydration of white cabbage: Drying mechanism, bioactive profile, color and rehydration property. Ultrason. Sonochem. 2019, 53, 192-201. [CrossRef] [PubMed]

13. Puig, A.; Perez-Munuera, I.; Carcel, J.A.; Hernando, I.; Garcia-Perezb, J.V. Moisture loss kinetics and microstructural changes in eggplant (Solanum melongena L.) during conventional and ultrasonically assisted convective drying. Food Bioprod. Process. 2012, 90, 624-632. [CrossRef]

14. Gamboa-Santos, J.; Montilla, A.; Cárcel, J.A.; Villamiel, M.; Garcia-Perez, J.V. Air-borne ultrasound application in the convective drying of strawberry. J. Food Eng. 2014, 128, 132-139. [CrossRef]

15. Ozuna, C.; Gómez Álvarez-Arenas, T.; Riera, E.; Cárcel, J.A.; Garcia-Perez, J.V. Influence of material structure on air-borne ultrasonic application in drying. Ultrason. Sonochem. 2014, 21, 1235-1243. [CrossRef] [PubMed]

16. Cruz, L.; Clemente, G.; Mulet, A.; Ahmad-Qasem, M.H.; Barrajón-Catalán, E.; García-Pérez, J.V. Air-borne ultrasonic application in the drying of grape skin: Kinetic and quality considerations. J. Food Eng. 2016, 168, 251-258. [CrossRef]

17. Rawson, A.; Tiwari, B.K.; Tuohy, M.G.; O’Donnell, C.P.; Brunton, N. Effect of ultrasound and blanching pretreatments on polyacetylene and carotenoid content of hot air and freeze dried carrot discs. Ultrason. Sonochem. 2011, 18, 1172-1179. [CrossRef]

18. Chungcharoen, T.; Prachayawarakorn, S.; Tungtrakul, P.; Soponronnarita, S. Effects of germination time and drying temperature on drying characteristics and quality of germinated paddy. Food Bioprod. Process. 2015, 94, 707-716. [CrossRef] 
19. Castro, G.A.; Fiorentini, E.F.; Wuilloud, R.G. Ionic liquid-assisted separation and determination of selenium species in food and beverage samples by liquid chromatography coupled to hydride generation atomic fluorescence spectrometry. J. Chromatogr. A 2017, 1491, 117-125. [CrossRef]

20. Wang, L.; Chen, J.; Xie, H.; Ju, X.; Liu, R.H. Phytochemical profiles and antioxidant activity of adlay varieties. J. Agric. Food Chem. 2013, 61, 5103-5113. [CrossRef]

21. Tao, Y.; Wang, P.; Wang, Y.; Kadam, S.U.; Han, Y.; Wang, J.; Zhou, J. Power ultrasound as a pretreatment to convective drying of mulberry (Morus alba L.) leaves: Impact on drying kinetics and selected quality properties. Ultrason. Sonochem. 2016, 31, 310-318. [CrossRef]

22. Ren, F.; Perussello, C.A.; Zhang, Z.; Kerry, J.P.; Tiwaria, B.K. Impact of ultrasound and blanching on functional properties of hot-air dried and freeze dried onions. LWT Food Sci. Technol. 2018, 87, 102-111. [CrossRef]

23. Do Nascimento, E.M.G.C.; Mulet, A.; Ascheri, J.L.R.; De Carvalho, C.W.P.; Carcel, J.A. Effects of high-intensity ultrasound on drying kinetics and antioxidant properties of passion fruit peel. J. Food Eng. 2016, 170, 108-118. [CrossRef]

24. Santacatalina, J.V.; Rodríguez, O.; Simal, S.; Cárcel, J.A.; Mulet, A.; García-Pérez, J.V. Ultrasonically enhanced low-temperature drying of apple: Influence on drying kinetics and antioxidant potential. J. Food Eng. 2014, 138, 35-44. [CrossRef]

25. Lekcharoenkul, P.; Tanongkankit, Y.; Chiewchan, N.; Devahastin, S. Enhancement of sulforaphane content in cabbage outer leaves using hybrid drying technique and stepwise change of drying temperature. J. Food Eng. 2014, 122, 56-61. [CrossRef]

26. Zou, K.; Teng, J.; Huang, L.; Dai, X.; Wei, B. Effect of osmotic pretreatment on quality of mango chips by explosion puffing drying. LWT Food Sci. Technol. 2013, 51, 253-259. [CrossRef]

27. Tao, Y.; Sun, D.-W.; Górecki, A.; Blaszczak, W.; Lamparski, G.; Amarowicz, R.; Fornal, J.; Jeliński, T. Effects of high hydrostatic pressure processing on the physicochemical and sensorial properties of a red wine. Innov. Food Sci. Emerg. Technol. 2012, 16, 409-416. [CrossRef]

28. Szadzin’ska, J.; Łechtan’ska, J.; Kowalski, S.J.; Stasiak, M. The effect of high power airborne ultrasound and microwaves on convective drying effectiveness and quality of green pepper. Ultrason. Sonochem. 2017, 34, 531-539. [CrossRef]

29. Multari, S.; Marsol-Vall, A.; Keskitalo, M.; Yang, B.; Suomela, J.-P. Effects of different drying temperatures on the content of phenolic compounds and carotenoids in quinoa seeds (Chenopodium quinoa) from Finland. J. Food Compos. Anal. 2018, 72, 75-82. [CrossRef]

30. Zhao, D.; Wei, J.; Hao, J.; Han, X.; Ding, S.; Yang, L.; Zhang, Z. Effect of sodium carbonate solution pretreatment on drying kinetics, antioxidant capacity changes, and final quality of wolfberry (Lycium barbarum) during drying. LWT Food Sci. Technol. 2019, 99, 254-261. [CrossRef]

31. Rahman, N.F.A.; Shamsudin, R.; Ismail, A.; Shah, N.N.A.K.; Varithd, J. Effects of drying methods on total phenolic contents and antioxidant capacity of the pomelo (Citrus grandis (L.) Osbeck) peels. Innov. Food Sci. Emerg. Technol. 2018, 50, 217-225. [CrossRef]

32. Rodríguez, Ó.; Santacatalina, J.V.; Simal, S.; Garcia-Perez, J.V.; Femenia, A.; Rosselló, C. Influence of power ultrasound application on drying kinetics of apple and its antioxidant and microstructural properties. J. Food Eng. 2014, 129, 21-29.

(C) 2019 by the authors. Licensee MDPI, Basel, Switzerland. This article is an open access article distributed under the terms and conditions of the Creative Commons Attribution (CC BY) license (http://creativecommons.org/licenses/by/4.0/). 